\title{
The proteins of synaptic vesicle membranes are affected during ageing of rat brain
}

\author{
Sae-Ra Lee', Ah-Ram Kim ${ }^{1}$, Jun-Sub Kim', \\ Jaebong Kim ${ }^{1}$, Jae-Yong Lee ${ }^{1}$, Yun-Lyul Lee ${ }^{2}$, \\ Myeon $\mathrm{Choe}^{3}$ and Jae-Bong Park ${ }^{1,4}$ \\ ${ }^{1}$ Department of Biochemistry, College of Medicine, Hallym Univer- \\ sity, Chunchon, Kangwon-Do 200-702, Korea \\ ${ }^{2}$ Department of Physiology, College of Medicine, Hallym University \\ ${ }^{3}$ Department of Animal Products Science, Kangwon National \\ University, Chunchon, Kangwon-Do 200-701, Korea \\ ${ }^{4}$ Corresponding author: Tel, +82-33-240-1621; \\ Fax, +82-33-244-8425; E-mail, jbpark@ hallym.ac.kr
}

\section{Accepted 20 November 2001}

Abbreviations: CaM, calmodulin; GDI, guanine nucleotide dissociation inhibitor; SV, synaptic vesicle; LP2 membrane, crude synaptic vesicle membrane; GEP, guanine nucleotide exchange protein; CaMK, calmodulin-dependent protein kinase; PKA, protein kinase A; PKC, protein kinase C; PA, phosphatidic acid; PI, phosphatidyl inositol

\begin{abstract}
Low molecular weight GTP-binding proteins are molecular switches that are believed to play pivotal roles in cell growth, differentiation, cytoskeletal organization, and vesicular trafficking. Rab proteins are key players in the regulation of vesicular transport, while Rho family members control actin-dependent cell functions, i.e. the regulation of cytoskeletal organization in response to extracelluar growth factors and in dendritic neuron development. In this study, we have examined the regulation of small GTP-binding proteins that are implicated in neurosecretion and differentiation of neuron during ageing processes. Comparison of small GTP-binding proteins from the synaptosome and crude synaptic vesicles (LP2 membranes) of 2 months and 20 months old rat brain respectively showed no difference in the level of Rab family proteins (Rab3A and Rab5A). However, Rho family proteins such as RhoA and Cdc42 were elevated in LP2 membranes of the aged brain. The dissociation of Rab3A by $\mathrm{Ca}^{2+} /$ calmodulin (CaM) from SV membranes was not changed during aging. $\mathrm{Ca}^{2+} / \mathrm{CaM}$ stimulated phosphorylation of the 22 and 55-kDa proteins in SV membranes from the aged rat brain, and inhibited phosporylation of $30-\mathrm{kDa}$ pro-
\end{abstract}

teins. GTP $\boldsymbol{S}$ inhibited phosphorylation of the 100$\mathrm{kDa}$ proteins and stimulated phosphorylation of the $70 \mathrm{kDa}$ in LP2 membranes from both the young and aged rat brains, whereas GDP $\beta S$ caused just the opposite reaction. These results suggest that protein phosphorylation and regulation of Rho family GTPases in rat brain appears to be altered during ageing processes.

Keywords: Small GTP-binding proteins, Rab3A, Rab5, Cdc42, RhoA, guanine nucleotides, Phosphorylation, Synaptic vesicle

\section{Introduction}

Synaptic transmission is the exchange of information in the brain, which is performed by the release of neurotransmitters from its presynaptic nerve endings. The neurotransmitters are stored in small organelles of the synaptic vesicles (SVs) in the resting stage. When the neuron is stimulated, an action potential is generated and arrives in the nerve terminal, the membrane depolarizes and voltage-gated $\mathrm{Ca}^{2+}$ channels open. The resulting $\mathrm{Ca}^{2+}$ influx triggers exocytosis of synaptic vesicles, leading to the release of neurotransmitter (Jahn and Südhof, 1994; Bauerfeind et al., 1996). SVs have many important protein sets such as synapsins, synaptotagmin, synaptobrevin/vesicle associated membrane protein (VAMP), synaptophysin, synaptophorin, SCAMPs, neurotransmitter transporters, proton pump, SV2, and Rab3A (Südhof, 1995). Exocytosis of synaptic vesicles requires the formation of fusion complex consisting of synaptobrevin, which is localized in synaptic vesicle, and syntaxin and SNAP-25, which is localized in presynaptic plasma membranes (Söllner et al., 1993).

Rab3A is Ras-related small GTP-binding protein, and is most abundant in brain, especially on SVs (Jahn and Südhof, 1994). It was reported that Rab3A plays as a regulator for the neurosecretion (Holz et al., 1994; Johannes et al., 1994; Johannes et al., 1998). Both Rab3A and Rab3C dissociate quantitatively from the vesicle membrane after $\mathrm{Ca}^{2+}$-dependent exocytosis and this dissociation is partially reversible during recovery after stimulation (Fischer von Mollard et al., 1991; 1994). A considerable portion of Rab3A in brain is cytosolic, and this cytosolic Rab3A is complexed to guanine nucleotide dissociation inhibitor (GDI), a protein capable of dissociating Rab proteins from membranes (Ullrich, 1993). It was reported that $\mathrm{Ca}^{2+} /$ calmodulin (CaM) could 
also dissociate Rab3A from SV, and forming a 1:1 complex of Rab3A-CaM (Park et al., 1997). RalA, another Ras-related small GTP-binding protein, was reported to be also an abundant protein in SV (Bielinski et al., 1993). RalA forms also a complex with $\mathrm{CaM}$ in a $\mathrm{Ca}^{2+}$ dependent manner (Wang et al., 1997), and is dissociated by $\mathrm{Ca}^{2+} / \mathrm{CaM}$ from LP2 membranes (Park et al., 1999). In addition, $\mathrm{Ca}^{2+}$ and CaM regulate the GTPbinding state of RalA, thereby they are supposed to regulate the activity of RalA (Park, 2001).

The synapse and SVs including membrane proteins are changed along with aging. Synaptic density is decreased during aging, and specifically, there is a significant decline in presumptive inhibitory synaptic terminals as well as a significant decline in synapses that contact dendritic spines (Brunso-Bechtold et al., 2000). Furthermore, dystrophic neurites of senile plaques are defective in proteins that control exocytosis and neurotransmission. Most neuritic senile plaques have a decreased level of synaptophysin, synaptotagmin and Rab3A, whereas SNAP-25 exists at the level of normal neurites (Ferrer et al., 1998). It was found that synaptobrevin also binds to synaptophysin and that synaptophysin-bound synaptobrevin cannot form the fusion complex (Calakos and Scheller, 1994; Edelmann et al., 1995). In recent years, it was found that synaptophysin-synaptobrevin complex is upregulated during neuronal development (Becher et al., 1999).

Protein phosphorylation is an important regulator of long-term synaptic plasticity and is also a direct and rapid modulator of exocytosis in neurons and most other cell types (Turner et al., 1999). Synapsin (Benfenati et al., 1992), 25-kDa synaptosomal associated protein (SNAP25), syntaxin 1, VAMP (Söllner et al., 1993), two soluble proteins such as SNAP and NSF (Hirling and Scheller, 1996), synaptotagmin (Bennett et al., 1993), and synaptophysin (Rubenstein et al., 1993) are phosphorylated. Raphyllin3A is also phosphorylated in vitro by CaMKII and PKA (Fykse and Südhof, 1995). Phosphorylated proteins were associated with altered functional properties, hence it could be thought that protein phosphorylation of SV might be altered during ageing leading to the malfunction of brain.

Thus, we tried to elucidate the possibility that the behavior of Rab3A by $\mathrm{Ca}^{2+} / \mathrm{CaM}$ may be changed during ageing, which is anticipated to be a malfunction of brain in aged brain. In addition, we analyzed the phosphorylation of proteins in LP2 membranes during ageing in rat brain.

\section{Materials and Methods}

\section{Materials}

CaM and RabGDI were purified from bovine brain.
$\mathrm{CaCl}_{2}$, suprapure grade, was from EM Science. GDP, GDP $\beta S$, and GTP $\gamma S$ were from Calbiochem. Glycine, SDS, Tween-20 and Tris/base, electrophoresis grade, were from Bio-Rad. PVDF membrane was from Millipore. Anti-Rab3A, -RalA, -Cdc42, and -RhoA antibodies and peroxidase-conjugated anti-rabbit IgG antibody were purchased from Santa-Cruz. Aprotinin, leupeptin, pepstatin A, PMSF, BSA, and other reagents were purchased from Sigma.

\section{Preparation of LP2 membranes from rat brain}

Synaptosomes were prepared from the brain of the young ( 2 months) and the old (20 months) SD rat by using Ficoll gradient method (Fisher von Mollard et al., 1991; Park et al., 1997). Crude SV, which contains Rab3A-enriched membranes, was prepared through lysis of synaptosome in hypotonic solution, and it has been also referred to as LP2 membranes (Huttner et al., 1983; Park et al., 1997).

\section{Purification of CaM}

Calmodulin was purified from bovine brain as described with a few modifications (Gopalakrishna and Anderson, 1982; Lee et al., 1995) from $350 \mathrm{~g}$ of bovine brain. The homogenate of rat brain (SD) was prepared by Warring blender and Potter-Elvehjem homogenizer in one volume of $30 \mathrm{mM}$ Hepes, pH 7.4, 2 mM EDTA, 2 mM EGTA, 1 $\mathrm{mM} \mathrm{CaCl}_{2}, 1 \mathrm{mM}$ DTT, $1 \mathrm{mM}$ PMSF, $4 \mu \mathrm{g} / \mathrm{ml}$ aprotinin, $2 \mu \mathrm{g} / \mathrm{ml}$ leupeptin. The supernatant of brain homogenate was obtained at $66,000 \mathrm{~g}, 4^{\circ} \mathrm{C}$ for $30 \mathrm{~min}$, and the supernatant solution was adjusted to a $\mathrm{CaCl}_{2}$ concentration of $5 \mathrm{mM}$, heated at $85^{\circ} \mathrm{C}$ for $3 \mathrm{~min}$, and cooled on ice. Heat-aggregated material was removed by centrifugation at $12,000 \mathrm{~g}$ for $30 \mathrm{~min}$ at $4^{\circ} \mathrm{C}$. The supernatant was loaded to a $50 \mathrm{ml}$ bed volume of phenyl-Sepharose column pre-equilibrated in buffer I (30 mM Hepes, $\mathrm{pH}$ 7.4, $1 \mathrm{mM} \mathrm{CaCl}_{2}, 0.1 \mathrm{mM}$ DTT), and the gel was washed with 10 column volumes of buffer I and 5 column volumes of buffer II (30 mM Hepes, pH 7.5, 200 mM $\mathrm{NaCl}, 1 \mathrm{mM} \mathrm{CaCl}_{2}, 0.1 \mathrm{mM}$ DTT). The bound CaM was eluted with buffer III (30 mM Hepes, pH 7.4, 2 mM EGTA, $0.1 \mathrm{mM}$ DTT), and CaM fractions were pooled together and concentrated to $1.5 \mathrm{ml}$ using ultrafiltration with PM10 membrane (Amicon). Glycerol was added to final concentration of $5 \%(\mathrm{v} / \mathrm{v})$ as a stabilizer, and aliquots of CaM were stored at $-70^{\circ} \mathrm{C}$. Coomassie staining of CaM-run SDS-PAGE gel showed a single band.

\section{Purification of RabGDI}

RabGDI was purified from bovine brain as described with a little modification from $450 \mathrm{~g}$ bovine brain (Sasaki et al., 1990). The brain was homogenized by a Waring Blender and a Potter-Elvehjem Teflon-glass homogenizer in 2 volumes of $25 \mathrm{mM}$ Tris, pH 7.5, $1 \mathrm{mM}$ DTT, $1 \mathrm{mM}$ $\mathrm{MgCl}_{2}, 1 \mathrm{mM}$ EGTA, $1 \mathrm{mM}$ PMSF, $2 \mu \mathrm{g} / \mathrm{ml}$ aprotinin, 2 
$\mu \mathrm{g} / \mathrm{ml}$ leupeptin, and $1 \mu \mathrm{g} / \mathrm{ml}$ pepstatin A (Buffer A). Tissue debris was removed by ultracentrifugation at $100,000 \mathrm{~g}, 4^{\circ} \mathrm{C}$ for $1 \mathrm{~h}$. The clear supernatant was loaded on DEAE-sephacel column $(5 \times 40 \mathrm{~cm})$. The column was washed with 8 liters of Buffer $A$ and the GDI fraction was eluted with Buffer $A$ containing $0.3 \mathrm{M} \mathrm{NaCl}$. The eluted solution was treated with $40 \%$ ammonium sulfate and incubated on ice for $30 \mathrm{~min}$. The $40 \%$ ammonium sulfate pellet was removed by centrifugation at $20,000 \mathrm{~g}, 4^{\circ} \mathrm{C}$ for $20 \mathrm{~min}$ and the supernatant was treated with $60 \%$ ammonium sulfate and incubated for $50 \mathrm{~min}$ on ice. The $60 \%$ ammonium sulfate pellet was saved by centrifugation at $20,000 \mathrm{~g}, 4^{\circ} \mathrm{C}$ for $20 \mathrm{~min}$. The pellet was resuspended in Buffer $\mathrm{B}$ ( $25 \mathrm{mM}$ Tris, $\mathrm{pH} 7.5$, $1 \mathrm{mM}$ DTT, $0.5 \mathrm{mM}$ EDTA, $1 \mathrm{mM}$ EGTA, $1 \mathrm{mM}$ PMSF, $2 \mu \mathrm{g} / \mathrm{ml}$ aprotinin, $2 \mu \mathrm{g} / \mathrm{ml}$ leupeptin, and $1 \mu \mathrm{g} / \mathrm{ml}$ pepstatin A) containing $10 \%$ glycerol and dialyzed against this buffer. Then sodium cholate was added to $1 \%(\mathrm{w} / \mathrm{v})$ in the solution to break Rab/RabGDI complex and $\mathrm{pH}$ of the solution was adjusted to be 8.0 by adding $1 \mathrm{M}$ Trizma/base. One third of the solution was loaded on Mono-Q column $(1 \times 10 \mathrm{~cm})$ equilibrated with Buffer B containing $1 \%$ sodium cholate and $10 \%$ glycerol. The column was washed with $200 \mathrm{ml}$ of the same buffer and the elution was performed with a $180 \mathrm{ml}$ Buffer $\mathrm{B}$ and $180 \mathrm{ml}$ Buffer B containing $0.5 \mathrm{M} \mathrm{NaCl}, 1 \%$ sodium cholate and $10 \%$ glycerol using a linear gradient. About $11 \mathrm{mg}$ of pure GDI was obtained from $450 \mathrm{~g}$ of bovine brain. Aliquots of purified RabGDI solution were stored at $-70^{\circ} \mathrm{C}$ before use.

\section{Dissociation of Rab3A from LP2 membranes}

LP2 membranes (60 $\mu \mathrm{g}$ protein) were incubated at $30^{\circ} \mathrm{C}$ for $30 \mathrm{~min}$ with various additives in $50 \mu \mathrm{l}$ of buffer (50 $\mathrm{mM}$ Hepes, $\mathrm{pH} 7.4,0.5 \mu \mathrm{M} \mathrm{MgCl}_{2}, 1 \mathrm{mM}$ DTT, $2 \mu \mathrm{g} / \mathrm{ml}$ aprotinin, and $2 \mu \mathrm{g} / \mathrm{ml}$ leupeptin). The reaction mixtures were centrifuged for $30 \mathrm{~min}$ at $100,000 \mathrm{~g}$ in a Beckman TLA45 rotor. The supernatants were stored at $-70^{\circ} \mathrm{C}$ and the pellets were resuspended in $50 \mu \mathrm{l}$ of the same buffer with brief sonication and vortexing. Western Blotting using anti-Rab3A or -RalA antibody and peroxidasecongugated anti-lgG antibody was performed to measure the levels of Rab3A or RalA from supernatants and membrane pellets (Park et al., 1997; 1999).

\section{Phosphorylation assay}

Kinase reactions were performed using endogenous membrane kinase of LP2 membranes in $10 \mu \mathrm{l}$ of the kinase buffer (5 mM Hepes, $\mathrm{pH} 7.4,0.05 \mu \mathrm{M} \mathrm{MgCl}_{2}, 0.1$ $\mathrm{mM}$ DTT, $0.2 \mu \mathrm{g} / \mathrm{ml}$ aprotinin, $0.2 \mu \mathrm{g} / \mathrm{ml}$ leupeptin, 100 $\mu \mathrm{M} \mathrm{Na}_{3} \mathrm{VO}_{4}, 3 \mathrm{mM} \beta$-glycerophosphate) in the presence of $0.1 \mathrm{mM}$ GDP $\beta S$, or $0.1 \mu \mathrm{M}$ GTP $\gamma \mathrm{S}$, and then $2 \mu \mathrm{Ci}[\gamma-$ $\left.{ }^{32} \mathrm{P}\right]$ ATP and $1 \mathrm{mM} \mathrm{MgCl}_{2}$ were treated to the SV membranes. The mixture was incubated at $30^{\circ} \mathrm{C}$ for 30 min and the reaction was stopped by the addition of 2.5 $\mu \mathrm{l}$ of SDS-PAGE sample buffer. The sample was resolved on SDS-PAGE (15\% or $7-15 \%$ gradient gel) and ${ }^{32} \mathrm{P}$ labeled proteins were subsequently detected by autoradiography on the dried gel.

\section{Results and Discussion}

Synaptic density, especially presumptive inhibitory synaptic terminals and synapses that contact dendritic spines, are changed during ageing (Brunso-Bechtold et al., 2000). In addition, dystrophic neurites of senile plaques have decreased the level of proteins that controls exocytosis and neurotransmission, such as synaptophysin, synaptotagmin and Rab3A (Ferrer et al., 1998).

Thus, we determined the level of Rab3A and Rab5A in the aged rat brain by Western blotting, showing that Rab3A and Rab5 of LP2 membranes were not significantly changed during ageing. On the contrary, RhoA and $\mathrm{Cdc42}$ were increased in SV of the aged rat brain (Figure 1), and RhoA was also increased in the aged human fibroblast (data not shown). These results indicate that Rab family proteins are relatively constant, while Rho family proteins are increased during aging. Rho family proteins may be related to the morphological change of senescent cells and neurite deformation of the aged brain. The expression of other synaptic proteins is differentially regulated during development and ageing. Synaptophysin, SNAP-25, synaptobrevin, and synaptotagmin are increased, whereas syntaxin and drebrin are decreased during ageing (Shimohama et al., 1998). Thus the decrease of Rho proteins in SV of the aged rat brain may be a specific phenomenon.

Recently, it was reported that CaM/Rab3A complex

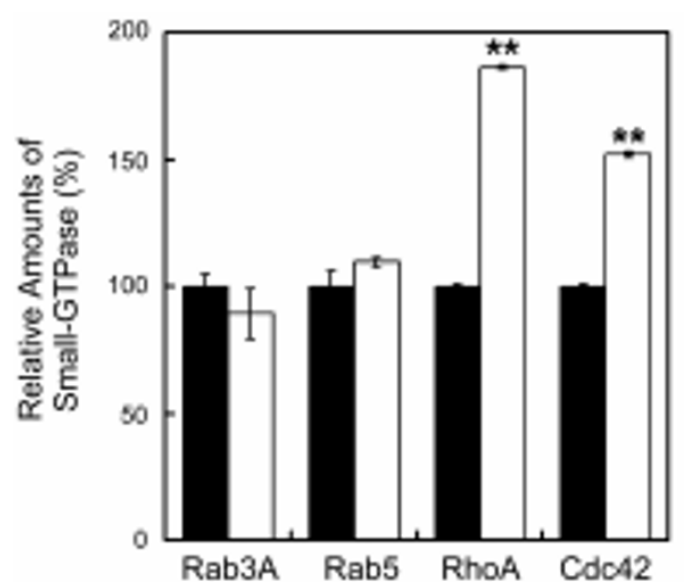

Figure 1. Amounts of small GTP-binding proteins of LP2 membranes during ageing. SV membranes (18 $\mu$ g protein) of young ( $\boldsymbol{q}$ ) and old $(\square)$ rat brain was loaded on SDS-PAGE, and Rab3A, Rab5, RhoA, and Cdc42 were analyzed with Western blotting by using anti-Rab3A, -Rab5, -RhoA, and Cdc42 antibodies. The values expressed as means \pm S.E $(n=3)$ shows statistically significant difference $\left({ }^{* *} p<0.01\right)$. 


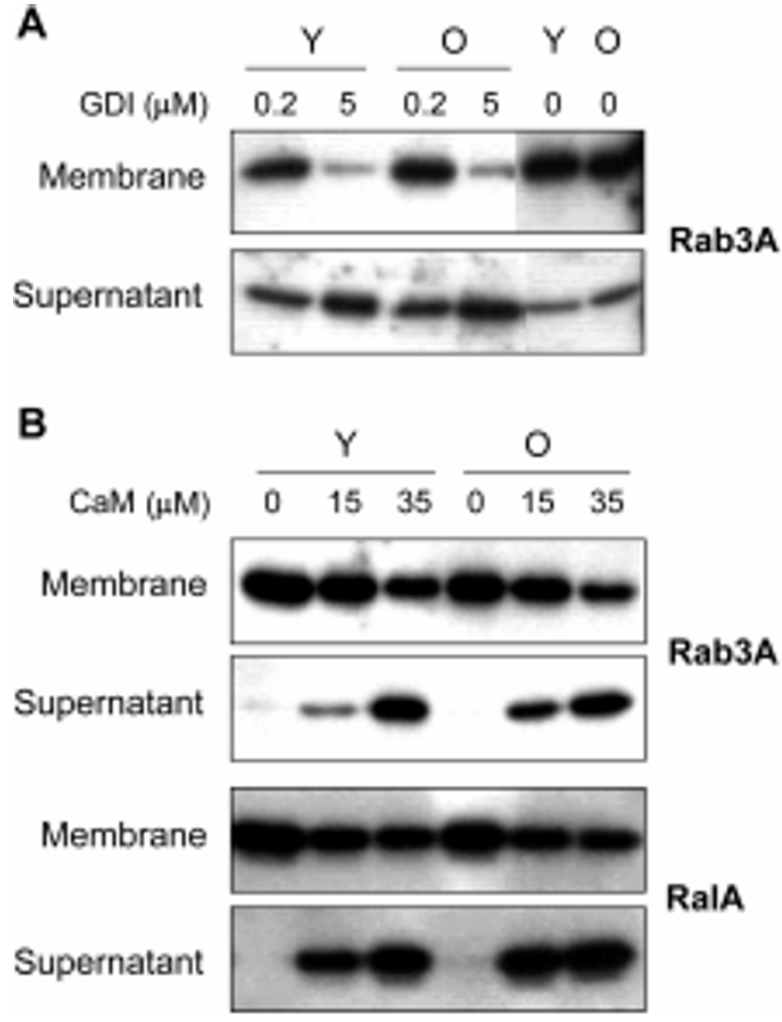

Figure 2. Dissociation of Rab3A from LP2 membranes by GDI and $\mathrm{Ca}^{2+}$ CaM. SV membranes (15 $\mu$ g protein) of young $(\mathrm{Y})$ and old $(0)$ rat brain were incubated with 0.2 and $5 \mu \mathrm{M} \mathrm{GDI}(\mathrm{A})$, and with 15 and $35 \mu \mathrm{M} \mathrm{CaM}$ in the presence of $0.1 \mathrm{mM} \mathrm{CaCl} 2(B)$ at $30^{\circ} \mathrm{C}$ for $30 \mathrm{~min}$, respectively. Membrane fraction was collected by ultracentrifugation at $100,000 \mathrm{~g}, 4^{\circ} \mathrm{C}$ for $30 \mathrm{~min}$, and Rab3A and RalA of the membrane pellet and the supernatant were quantitated by Western blotting by using anti-Rab3A and -RalA antibodies. The results were representatives of at least three independent experiments.

formation and translocation of Rab3A are very important for the secretion. $\mathrm{Ca}^{2+}$-dependent association of CaM with Rab3A correlates with insulin exocytosis in pancreatic $\beta$ cells (Kajio et al., 2001), and Rab3A is absent in endocytic SV indicating that Rab3A is dissociated from SV during endocytosis (Maycox et al., 1992). Although the amount of Rab3A was not changed during ageing, there was a possibility that the behavior of Rab3A may be changed during ageing. To test this possibility, the dissociation of Rab3A from LP2 membranes by $\mathrm{Ca}^{2+} / \mathrm{CaM}$ or by RabGDI was examined. The purified GDI and CaM were incubated with SV membranes to allow dissociation of Rab3A and RalA, and the dissociated Rab3A and RalA were determined by Western blot analysis. GDI dissociated Rab3A from LP2 membranes, while $\mathrm{Ca}^{2+} / \mathrm{CaM}$ did both Rab3A and RalA. However, the extent of Rab3A and RalA dissociation from LP2 membranes were found to be similar from the young and aged rat brains (Figure 2). Rab3A from the LP2 membranes of the aged rat brain appeared to dissociate at a lower concentration of $\mathrm{CaM}(15 \mu \mathrm{M})$ than the young rat brain but it was not significant. The results indicate that the dissociation of Rab3A and RalA from LP2 membranes by $\mathrm{Ca}^{2+} / \mathrm{CaM}$ or RabGDI is not a main factor for the malfunction of brain in the aged rat.

The translocation of Rab3A from Rab3A-RabGDI complex to the membrane is stimulated by phosphatidic acid (PA) in membrane (Jung et al., 1999). The activation of small GTP-binding proteins has been generally executed through GTP binding with the aid of GDP/GTP exchange factor. A GDP/GTP exchange protein (GEP) specific to the Rab3A subfamily has been purified and characterized in recent years (Wada et al., 1997). Rab3 GEP, however, is inactive on Rab3 complexed with RabGDI. In addition, the interaction of Rac-RhoGDI complex is disrupted in the presence of various lipids like arachidonic acid, PA, and phosphatidylinositol (PI), which were shown to possess biological activities in a variety of systems (Chuang et al., 1993). Phosphorylation of RhoGDI stabilizes the RhoA-RhoGDI complex in neutrophil cytosol, and RhoA and RhoGDI components are released to their free form upon treatment of this complex with alkaline phosphatase (Bourmeyster and Vignais, 1996). As shown in the previous reports, the translocation of small GTP-binding proteins is regulated by several factors. However, the regulation of translocation of Rab3A from $\mathrm{Ca}^{2+} / \mathrm{CaM}-\mathrm{Rab} 3 \mathrm{~A}$ complex has to be elucidated. Taken together, these results suggest LP2 membranes of both young and old rat brain may not have changed in the regulatory factors of translocation of Rab3A and RalA.

The protein phosphorylation is important for the regulation of neurosecretion. $\mathrm{Ca}^{2+}$ caused an elevation of 50 $\mathrm{kDa}$ protein (p50) phosphorylation in LP2 membrane of the young rat brain but the addition of $\mathrm{CaM}$ reduced phosphorylation of the same protein, while the phosphorylation of $55 \mathrm{kDa}$ protein (p55) was activated by $\mathrm{Ca}^{2+}$ / $\mathrm{CaM}$. It is still to be clarified whether $\mathrm{Ca}^{2+} / \mathrm{CaM}$ relates the activation to the dissociation of Rab3A. Guanine nucleotides have some effects on the phosphorylation of the proteins in LP2 membranes. GTP $\gamma S$ stimulated the phosphorylation of $70 \mathrm{kDa}$ protein (p70), but inhibited $100 \mathrm{kDa}$ protein (p100) phosporylation in both LP2 membranes from the young and aged rat brain, whereas GDP $\beta S$ caused just the opposite reaction (Figure 3A). This indicates that GTP-binding proteins may regulate the phosphorylation of the proteins in SV membranes.

In addition, $18 \mathrm{kDa}$ ( $\mathrm{p} 18)$ protein was phosphorylated in LP2 membranes of the young rat brain, whereas 22 $\mathrm{kDa}$ (p22) and $30 \mathrm{kDa}$ (p30) proteins were phosphorylated in the old rat brain (Figure 3B). The phosphorylation of p18 and p30 in the young and old brain respectively was inhibited in the presence of $\mathrm{Ca}^{2+} / \mathrm{CaM}$. In this step, it is still to be elucidated whether the inhibition of phosphorylation is due to the dissociation of small GTP-binding proteins or due to the activation of $\mathrm{Ca}^{2+} / \mathrm{CaM}$-dependent phosphatase like calcineurin. However, the possible involvement of nonspecific $\mathrm{Ca}^{2+}$ / 

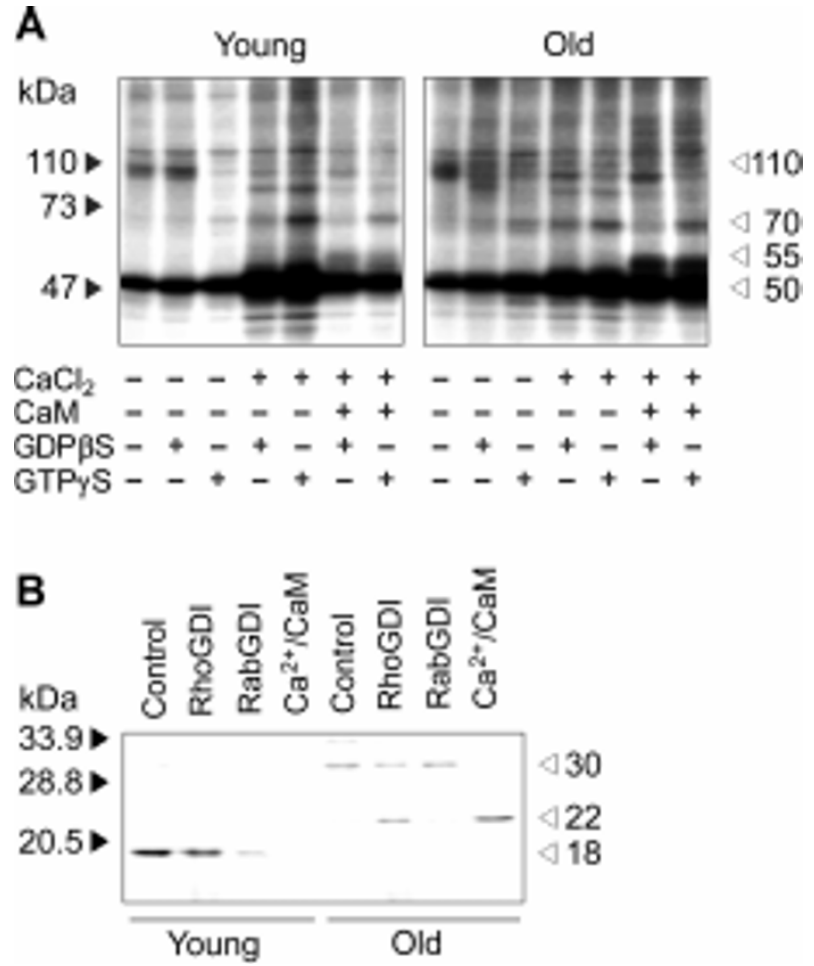

Figure 3. Phosphorylation of proteins in SV membranes. SV membranes (15 $\mu \mathrm{g}$ protein) of young $(\mathrm{Y})$ and old $(\mathrm{O})$ rat brain were incubated with 35

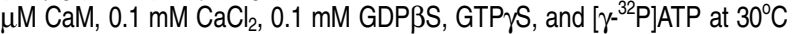
for $30 \mathrm{~min}(\mathrm{~A})$, and with, $1 \mu \mathrm{g}$ RhoGDI, $1 \mu \mathrm{g} \mathrm{RabGDI}$, and $35 \mu \mathrm{M} \mathrm{CaM}$ in the presence of $0.1 \mathrm{mM} \mathrm{CaCl}$, and then $\left[\gamma_{-}^{32}\right.$ P]ATP was added for the protein phosphorylation (B). The reaction samples were loaded on 7-15\% gradient gel (A) or 15\% SDS-PAGE gel (B), and the gel was dried and the autoradiography was performed. The results were representatives of at least three independent experiments.

CaM dependent phosphatase in the reduction of protein phosphorylation can be ruled out, where the phosphorylation of p22 was activated in the aged rat brain (Figure 3B). RabGDI, which dissociates Rab proteins, inhibited that of p18 in LP2 membranes of the young rat brain and RhoGDI, which dissociates Rho proteins, stimulated the phosphorylation of p22 in LP2 membranes of the old rat brain. These results indicate that dissociation of small GTP-binding proteins affect the phosphorylation of membrane proteins of SV, and that the species of small GTP-binding proteins involved in the regulation of protein phosphorylation in SV are different between the young and old rat brain.

Munc18, one of SV proteins, is phosphorylated in vitro by protein kinase $\mathrm{C}$ (PKC) and cyclin-dependent kinase 5 (Cdk5). Phosphorylated Munc18 have shown the reduced affinity for syntaxin $1 \mathrm{~A}$ but with some difference where phosphorylation by Cdk5 resulted in a greater reduction in syntaxin $1 \mathrm{~A}$ binding affinity (Shuang et al., 1996; Fletcher et al., 1999). The phosphorylation of SV proteins may alter physiological function. The mechanism and the physiological meaning on the change of phos- phorylation of SV from the aged rat brain is an interesting and anticipated observation and our results may provide some biochemical bases for further study.

\section{Acknowledgements}

The authors wish to acknowledge the financial support of the Korean Research Foundation in Program Year 1997 (\#1997-005-F00222).

\section{References}

Bauerfeind R, Galli T, De Camilli P. Molecular mechanisms in synaptic vesicle recycling. J Neurocytol 1996;25:701-15

Becher A, Drenckhahn A, Pahner I, Margittai M, Jahn R, Ahnert-Hilger $\mathrm{G}$. The synaptophysin-synaptobrevin complex: a hallmark of synaptic vesicle maturation. J Neurosci 1999;19: 1922-31.

Benfenati F, Valtorta F, Rubenstein JL, Gorelick FS, Greengard P, Czernik AJ. Synaptic vesicle-associated $\mathrm{Ca}^{2+}$ calmodulin-dependent protein kinase II is a binding protein for synapsin I. Nature 1992;359:417-20

Bennett MK, Miller KG, Scheller RH. Casein kinase II phosphorylates the synaptic vesicle protein p65. J Neurosci 1993;13:1701-7

Bielinski DF, Pyun HY, Linko-Stentz K, Macara IG, Fine RE. Ral and Rab3a are major GTP-binding proteins of axonal rapid transport and synaptic vesicles and do not redistribute following depolarization-stimulated synaptosomal exocytosis. Biochim Biophys Acta 1993;1151:246-56

Bourmeyster N, Vignais PV. Phosphorylation of RhoGDI stabilizes the Rho-RhoGDI complex in neutrophil cytosol. Biochem Biophys Res Comm 1996;218:54-60

Brunso-Bechtold JK, Linville MC, Sonntag WE. Age-related synaptic changes in sensorimotor cortex of the Brown Norway X Fischer 344 rat. Brain Res 2000;872:125-33

Calakos N, Scheller RH. Vesicle-associated membrane protein and synaptophysin are associated on the synaptic vesicle. $\mathrm{J}$ Biol Chem 1994;269:24534-37

Chuang TH, Bohl BP, Bokoch GM. Biologically active lipids are regulators of Rac-GDI complexation. J Biol Chem 1993; 268:26206-11

Edelmann L, Hanson PI, Chapman ER, Jahn R. Synaptobrevin binding to synaptophysin: a potential mechanism for controlling the exocytotic fusion machine. EMBO J. 1995;16: 224-31

Ferrer I, Marti E, Tortosa A, Blasi J. Dystrophic neurites of senile plaques are defective in proteins involved in exocytosis and neurotransmission. J Neuropathol Exp Neurol 1998;57: 218-25

Fischer von Mollard G, Stahl B, Khokhlatchev A, Südhof TC, Jahn R. Rab3C is a synaptic vesicle protein that dissociates 
from synaptic vesicles after stimulation of exocytosis. J Biol Chem 1994;269:10971-74

Fischer von Mollard G, Südhof TC, Jahn R. A small GTPbinding protein dissociates from synaptic vesicles during exocytosis. Nature 1991;349:79-81

Fletcher Al, Shuang RS, Giovannucci DR, Zhang L, Bittner ZA, Stuenkel EL. Regulation of exocytosis by cyclin-dependent kinase 5 via phosphorylation of Munc18. J Biol Chem 1999;274:4027-35

Fykse EM, Li C, Sudhof TC. Phosphorylation of rabphilin-3A by $\mathrm{Ca}^{2+}$-dependent and cAMP-dependent protein kinases in vitro. J Neurosci 1995;15:2385-95

Gopalakrishna R, Anderson WB. $\mathrm{Ca}^{2+}$-induced hydrophobic site on calmodulin: application for purification of calmodulin by Phenyl-Sepharose affinity chromatography. Biochem Biophys Res Commun 1982;104:830-36

Hirling $\mathrm{H}$, Scheller RH. Phosphorylation of synaptic vesicle proteins: modulation of the alpha SNAP interaction with the core complex. Proc Natl Acad Sci U.S.A. 1996;93:11945-49

Holz RW, Brondyk WH, Senter RA, Kuizon L, Macara IG, Evidence for the involvement of Rab3A in $\mathrm{Ca}^{2+}$-dependent exocytosis from adrenal chromaffin cells. J Biol Chem 1994;269:10229-34

Huttner WB, Schiebler W, Greengard P, De Camilli P. Synapsin I (protein I), a nerve terminal-specific phosphoprotein. III. Its association with synaptic vesicles studied in a highly purified synaptic vesicle preparation. J Cell Biol 1983; 96:1374-88

Jahn R, Sudhof TC. Synaptic vesicles and exocytosis. Annu Rev Neurosci 1994;17:219-46

Johannes L, Lledo P-M, Chameau P, Vicent JD, Henry JP, Darchen F. Regulation of $\mathrm{Ca}^{2+}$ : sensitivity of exocytosis by Rab3A. J Neurochem 1998;71:1127-33

Johannes L, Lledo PM, Roa M, Vincent J-D, Henry J-P, Darchen F. The GTPase Rab3a negatively controls calciumdependent exocytosis in neuroendocrine cells. EMBO J 1994; 13:2029-37

Jung YJ, Lee TH, Lee JY, Kim JH, Park JB. Phosphatidic acid is important to the translocation of Rab3A from the cytosol to phospholipid membranes. NeuroReport 1999;10: 2859-63

Kajio H, Olszewski S, Rosner PJ, Donelan MJ, Geoghegan $\mathrm{KF}$, Rhodes CJ. A low-affinity $\mathrm{Ca}^{2+}$-dependent association of calmodulin with the Rab3A effector domain inversely correlates with insulin exocytosis. Diabetes 2001;50:2029-39

Lee SH, Kim JC, Lee MS, Heo WD, Seo HY, Yoon HW, Hong JC, Lee SY, Bahk JD, Hwang I, Cho MJ. Identification of a novel divergent calmodulin isoform in soybean which has different ability to activate calmodulin-dependent enzymes. $J$ Biol Chem 1995;270:21806-12
Maycox PR, Link E, Reetz A, Morris SA, Jahn R. Clathrincoated vesicles in nervous tissue are involved primarily in synaptic vesicle recycling. J Cell Biol 1992;118:1379-88

Park JB, Farnsworth CC, Glomset JJ. $\mathrm{Ca}^{2+} /$ Calmodulin causes Rab3A to dissociate from synaptic membranes. J Biol Chem 1997;272:20857-65

Park JB, Lee JY, Kim JW. Dissociation of RalA from synaptic membranes by $\mathrm{Ca}^{2+} /$ calmodulin. Biochem Biophys Res Comm 1999;263:765-69

Park JB. Regulation of GTP-binding state in RalA through $\mathrm{Ca}^{2+}$ and calmodulin. Exp Mol Med 2001;33:54-58

Rubenstein JL, Greengard P, Czernik A. Calcium-dependent serine phosphorylation of synaptophysin. Synapse 1993;13: 161-72

Sasaki T, Kikuchi A, Akira S, Hata Y, Isomura M, Kuroda S, Takai $Y$. Purification and characterization from bovine brain cytosol of a protein that inhibits the dissociation of GDP from and the subsequent binding of GTP to smg p25A, a ras p21like GTP-binding protein. J Biol Chem 1990;265:2333-37

Shimohama S, Fujimoto S, Sumida Y, Akagawa K, Shirao T, Matsuoka $Y$, Taniguchi T. Differential expression of rat brain synaptic proteins in development and aging. Biochem Biophys Res Comm 1998;251:394-98

Shuang R, Zhang L, Fletcher A, Groblewski GE, Pevsner J, Stuenkel EL. Regulation of Munc-18/syntaxin1A interaction by cyclin-dependent kinase 5 in nerve endings. J Biol Chem 1998;273:4957-66

Söllner T, Whiteheart SW, Brunner M, Erdjument-Bromage H, Geromanos S, Tempst T, Rothman JE. SNAP receptors implicated in vesicle targeting and fusion. Nature 1993;362: 318-24

Südhof TC. The synaptic vesicle cycle: a cascade of proteinprotein interactions. Nature 1995;375:645-53

Turner KM, Burgoyne RD, Morgan A. Protein phosphorylation and the regulation of synaptic membrane traffic. Trends Neurosci 1999;22:459-64

Ullrich O, Stenmark H, Alexandrov K, Huber LA, Kaibichi K, Sasaki T, Takai Y, Zerial M, Rab GDP dissociation inhibitor as a general regulator for the membrane association of Rab proteins. J Biol Chem 1993;268:18143-50

Wada M, Nakanishi $H$, Satoh A, Hirano H, Obaishi H, Matsuura $Y$, Takai $Y$. Isolation and characterization of a GDP/ GTP exchange protein specific for the Rab3 subfamily small G proteins. J Biol Chem 1997;272:3875-78

Wang KL, Khan MT, Roufogalis BD. Identification and characterization of a calmodulin-binding domain in Ral-A, a Ras-related GTP-binding protein purified from human erythrocyte membrane. J Biol Chem 1997;274:16002-9 